\title{
The Parental Perspective on the New Media
}

\section{SibelOnursoy, Anadolu University, Turkey}

\begin{abstract}
Recently the use of the Internet by children and adolescents has become very extensive in Turkey. However, instead of a considered response to this issue, a sort of panic has been created by the mainstream media. Families have become greatly concerned.Adolescents' intense relationships with the Internet environment are seen as involving certain risks. But in general, the dynamics behind the attractiveness of the Internet are not discussed clearly at the level of children and young people. The impact of the Internet -which seems to make lives easier-on parents and how they guide their children on the Internet, is addressed in the study. The focus in this research is: Do the parents make rules about media usage? Is time limitations imposed on Internet usage, are parents aware of the Internet sites their children visit? Do they use security filters? Do they have sufficient information about the Internet and use of Internet? Do they have enough knowledge about Internet games? Do they make rules for all computer games or do they only control their children in terms of Internet games?

These issues are investigated by means of in-depthinterviews, which allow the researcher to explore the feelings and perspectives of parents regarding media and children.
\end{abstract}

Keywords: Media usage, Internet usage, Parental perspective. 


\section{Introduction}

Technological developments are constantly altering people's communication needs, especially through the catalytic effect of Internet. Children meet with the computer at an early age in today's society. They benefit largely from computers for entertainment, doing homework and at school. The so-called "Y generation" has grown up in a computerized world. They don't go to the library to do homework but find the information they want on the Internet and become cognizant of the world and different cultures in this way. After spending time with neighborhoodfriends during the day, they can chat with people from around the world in the evening. They are used to rapid change in the lives of all things - their adaptive competencies are very strong (Kaya, 2003:6). From this perspective, children and young people can use technology to as much advantage as adults and are equipped to develop their competence. Parents provide them with the beneficial opportunities of computer and Internet in terms of education, entertainment and communication.

Usage of computer and Internet involves both positive and negative returns. For example, the extensive information that exists on the Internet in terms of books, library research, experiment and observation marginalize the normal educational tools. Children can do their homework with little effort (Livingstone, 2001). On the other hand, they may consume excessive time on the computer and are brought face-to-face with physical, social and psychological development problems as well as with a variety of risks and security threats. Uncontrolled activity by children on the Internet has dangerous consequences; as if a parent were to leave a child alone outside the house (Canbek and Sagıroğlu, 2007:34). According to the World Tracker report, examined keywords in search engines, 82 of 200 of the most-used search words were associated with pornography. In addition $12 \%$ - of the content of websites on the Internet is pornographic (Bissette, 2003). Therefore, the likelihood of children and young people accessing such content is very high. According to a Turkish Statistical Institute report, Internet subscriptions in Turkey reached 8.672.376 in 2010 (TUIK, 2010). Meanwhile, mobile phone subscription is 61.769 .635 (Turkey population is 74.724.269 in December 31, 2011/http://www.tuik.gov.tr). Researches on children's Internet usage do not yet exist in Turkey.

According to Livingston's research (2005), focused on children in England, the extent of home Internet access among children is rapidly increasing. $60 \%$ of parents advise children 
that some sites should be avoided, 52\% make limit the hours of usage, and about $\% 39 \%$ of parents do not permit their children to meet personally with acquaintances made on the Internet (Livingstone and Bober, 2005). This study shows that parents have a specific intention when they make rules, although these are not adequate in terms of safety and risks.

For all these reasons, research on this issue is important in Turkey, including parents' perspectives on media developments, their own level of awareness, and the determination of behavior patterns. The Internet carries risks such as access to fatally harmful content, contact with malicious people, abuse or pedophilia. Other risks are as follows: publications with illegal content, information given to third parties that endanger themselves or their families for example addresses, credit card numbers, the number of people at home, who at that moment is communicating via e-mail or chat programs, shopping with a credit card without permission from their parents, communicating with malicious people and criminal organizations. Confronting harmful content at an early age is damaging to the development of children and youth. For young people to use the Internet effectively and efficiently, their safety should be kept in the foreground. Internet service providers (ISP) have produced solutions such as search engine filters to limiting access, and the client and server-side filter programs for the prevention of harmful content (Milliyet, 2006). However, to benefit from these solutions effectively, parents must be educated to use them properly, even though many Internet browsers have site structures that provide content filtering and consultation. Should it be concluded that parents lack sufficient information about the protection of their children from risk?

The aim of this study is to determine parents' perspectives on the changing media and their relevant level of awareness and patterns of behaviors. In this context, this study deals with parents' awareness, knowledge and use of the media and how parents shape their children's relationship with the Internet and social media.

\section{Methodology}

The semi-structured in-depth interview was used in this study. The interviews were conducted in May 2012 face-to-face with randomly selected parents with children in secondary and high school. The interviewees were asked questions about demographic information and were given the opportunity to talk about their conscious or unconscious 
behavior in the given context as well as their own experiences, relationships with their children, fear of the Internet, and the sources of these fears. The semi-structured face-to-face interviews with 12 families were conducted in the parents' workplaces or houses. These people were selected randomly on the basis of socio-economic status and level of education. Families living on the minimum wage represented the lower socio-economic status group, and families with a monthly income of " 2400 or over represented the upper socio-economic status group. The families' levels of education increased in parallel with their economic status. Families were identified as two groups according to the level of income and level of education. A named group of low-income and less educated and B named group of called high-income and highly educated.

\section{Findings}

In-depth interviews were conducted with 12 families. The age range of the family members was 34-51. Table 1 shows the demographic information about the parents and the number of children. In addition to the demographic questions in the semi-structured interviews, the following questions were asked at appropriate times and in a way that allows the parents to make comments. The interviewees were first asked to rank the means of communication they used most.In general, all of the families interviewed had a computer at home, one of the families had never had Internet connection at home, and another family had just removed the Internet connection from their house.

Table 1. Demographic characteristics

\begin{tabular}{|c|c|c|c|c|c|c|c|c|c|c|}
\hline \multirow[t]{2}{*}{ Family } & \multicolumn{3}{|c|}{ Mother } & \multicolumn{3}{|c|}{ Father } & \multirow{2}{*}{$\begin{array}{l}\text { Level of } \\
\text { income“ } \\
\text { (Monthly) }\end{array}$} & \multicolumn{3}{|c|}{ Child } \\
\hline & $\underline{\text { Age }}$ & $\underline{\text { Profession }}$ & Education & $\underline{\text { Age }}$ & $\underline{\text { Profession }}$ & $\underline{\text { Education }}$ & & $\mathrm{Nr}$. & Gender & $\underline{\text { Age }}$ \\
\hline$\underline{1}$ & $\underline{39}$ & Unemployed & Primary & $\underline{43}$ & Barber & Primary & $\underline{1000}$ & $\underline{2}$ & $\frac{1 \mathrm{~F}}{1 \mathrm{M}}$ & $\frac{10}{14}$ \\
\hline$\underline{2}$ & 34 & Cleaner & $\begin{array}{l}\text { High } \\
\text { school } \\
\end{array}$ & $\underline{35}$ & Worker & $\begin{array}{l}\text { Secondary } \\
\text { school }\end{array}$ & $\underline{1000}$ & $\underline{2}$ & $\frac{\mathrm{M}}{\text { (Twin) }}$ & $\frac{13}{13}$ \\
\hline$\underline{3}$ & $\underline{38}$ & $\underline{\text { Unemployed }}$ & Primary & $\underline{41}$ & Cleaner & Primary & $\underline{1500}$ & $\underline{2}$ & $\underline{\mathrm{M}}$ & $\overline{9}$ \\
\hline$\underline{4}$ & $\underline{35}$ & Cleaner & $\begin{array}{l}\text { Secondary } \\
\text { school }\end{array}$ & $\underline{41}$ & Cleaner & $\begin{array}{l}\text { Secondary } \\
\text { school }\end{array}$ & $\underline{1600}$ & $\underline{2}$ & $\frac{F}{M}$ & $\frac{14}{7}$ \\
\hline$\underline{5}$ & $\underline{42}$ & Unemployed & $\begin{array}{l}\text { Secondary } \\
\text { school }\end{array}$ & $\underline{48}$ & $\underline{\text { Technician }}$ & $\begin{array}{l}\text { High } \\
\underline{\text { school }}\end{array}$ & $\underline{2000}$ & $\underline{3}$ & $\frac{\underline{F}}{\mathrm{~F}}$ & $\frac{12}{12}$ \\
\hline$\underline{6}$ & $\underline{44}$ & $\underline{\text { Unemployed }}$ & $\begin{array}{l}\text { Secondary } \\
\text { school }\end{array}$ & $\underline{47}$ & $\underline{\text { Tradesman }}$ & $\begin{array}{l}\text { Secondary } \\
\underline{\text { school }}\end{array}$ & $\underline{2500}$ & $\underline{3}$ & $\begin{array}{l}\bar{F} \\
\underline{F} \\
\underline{F}\end{array}$ & $\frac{15}{\frac{17}{24}}$ \\
\hline$\underline{7}$ & $\underline{48}$ & $\underline{\text { Unemployed }}$ & Primary & $\underline{50}$ & Tradesman & $\begin{array}{l}\text { Secondary } \\
\text { school }\end{array}$ & 2000 & $\underline{2}$ & $\underline{\underline{\mathrm{M}}}$ & $\frac{26}{12}$ \\
\hline$\underline{8}$ & $\underline{38}$ & Cleaner & $\begin{array}{l}\text { Secondary } \\
\text { school }\end{array}$ & $\underline{38}$ & $\underline{\text { Technician }}$ & Academy & $\underline{2400}$ & $\underline{2}$ & $\begin{array}{l}\underline{\mathrm{F}} \\
\underline{\mathrm{M}} \\
\end{array}$ & $\begin{array}{l}\underline{8} \\
\underline{18} \\
\end{array}$ \\
\hline$\underline{9}$ & 37 & Teacher & Academy & $\underline{40}$ & Academician & Doctorate & 5000 & $\underline{1}$ & $\underline{M}$ & 11 \\
\hline$\underline{10}$ & $\underline{41}$ & Academician & Doctorate & $\underline{43}$ & Academician & Doctorate & $\overline{5000}$ & $\underline{1}$ & $\underline{\overline{\mathrm{M}}}$ & $\underline{12}$ \\
\hline$\underline{11}$ & $\underline{40}$ & Academician & Doctorate & 47 & Academician & Doctorate & $\underline{5000}$ & $\underline{1}$ & $\underline{\mathrm{M}}$ & $\underline{15}$ \\
\hline
\end{tabular}




\begin{tabular}{|l|l|l|l|l|l|l|l|l|l|l|}
\hline & & & & & Over & & & \\
\hline$\underline{12}$ & $\underline{43}$ & $\underline{\text { Academician }}$ & $\underline{\text { Doctorate }}$ & $\underline{51}$ & $\underline{\text { Doctor }}$ & $\underline{\text { Doctorate }}$ & $\underline{\underline{5000}}$ & $\underline{\text { Over }}$ & $\underline{\mathrm{F}}$ & $\underline{13}$ \\
\hline
\end{tabular}

The A group primarily used electronic media such as television, mobile phone and the Internet in that order. Housewives especially mentioned their habit of watching women's programs on daytime television. The children (11 years old) from two families in the upper socio-economic level did not have mobile phones. The children of the same age in the other families had mobile phones and only two 8-year-old children did not have mobile phones. The families of the Agroup used the Internet, but its use was usually limited to social networking sites like Facebook.

The parents of the high-income (Group B), better-educated group spent more time on electronic mass media than the others, most frequently the Internet, followed by mobile phones and television respectively. In general, these parents followed the news on the Internet and spent an average of 5-6 hours on the Internet during the day.

\section{Internet Habits, Reasons for Purchasing Internet Connection}

Parents from the A explain that they purchased Internet connection to help their children with research for their homework, to communicate with relatives, to download movies and music, and to visit social networking sites. This group used the Internet least and had the lowest level of relevant knowledge in this regard.

Internet habits of the A group: two families do not have Internet connection, one family had limited use of the Internet, and another one regretted having purchased it. The two main reasons for the purchase of Internet connection at home were to help their children do their homework and to communicate with distant relatives. They do not know much about the computer and do not receive any instruction concerning it. The mothers of this group have never used the computer or spend time and effort to master its use. Two of the fathers are able to use the computer but only for playing computer games. The children from two families in this group with no Internet connection at home go to Internet cafes. In these cafes, where they generally go to study and do homework, they play games as well. The mothers state that they often take their children to these cafes themselves and wait for them there. They also rent games for their computers at home. The children in this group possessed the skills to download and watch movies and music, to upload and share pictures and videos, to 
do research for homework and to use social networking sites like Facebook. This group often mentions the gap between them and their children in terms of the knowledge of the Internet and the computer. These children are more competent on the Internet and the computer than their parents. The adolescent children use the Internet in a number of ways such as online shopping and banking, chatting, doing research, downloading music and movies, and sharing them on social networks. Two of the mothers receive instruction about controlling their children's Internet use because they feel they are not as knowledgeable as their children about the computer. However, they state that they still have not been able to attain theirchildren's level of knowledge.

Internet habits of the B group: This is the group that used the new media most. In this group, the level of education is high as well as the economic level. The parents in this group are more knowledgeable about and familiar with the Internet and the computer due to their professions and spend 5-6 hours daily on the Internet or the computer. In general, all of them follow the development of the Internet. All of them except one set time-limits for Internet use by their children. The only family who uses a filter for the Internet said they prefer this method because they are unable to control their children due the demands of their jobs. The children from the families in this group use the Internet for online games or social networking sites like Facebook.

\section{Public Concern about the Internet, Parents' Negative View}

The A group's concerns about the Internet: This group considers the Internet unsafe. A parent in this group explained the damage caused by the Internet on the family as an institution by saying "the Internet destroys the family; Facebook causes divorces and damages the family". Another parent complained that the Internet undermined family ties, saying "my husband does not even take a break once he is online and we can no more discuss our problems or even have a chat". In general, the parents in this group complain that the Internet made people lazy, encouraged people to seek ready-made or free material, set bad examples for children because of violent online games, often encouraged children to use the computer for games, promoted obesity and exposed children to the danger of pornographic content. They also stated that they are disturbed by the fact that their children shared their pictures with special (exaggerated) poses for Facebook allowing intrusions on their privacy. They are worried that this kind of sharing can be abused. In their opinion, the Internet connection is 
first purchased for use at home as a source of research and information, but then it transforms into an addictive gaming tool. This group tends to see Internet use as unnecessary risk-taking; all of the parents in the group wish they hadn't let the Internet into their homes and they even want to return it. To sum up, they think the Internet is unsafe.

The first concern for these parents is that the Internet can be addictive. They think addiction to online games has prevented their children from studying school subjects and the parents themselves were subject to the same addiction when they first purchased an Internet connection. One of the mothers said, "Even my husband was hooked on the Internet and he was out of the real world for a while". Having hidden the computer to overcome her child's addiction, another mother said, "It was really hard; we couldn't make our son leave the computer and I had to hide it, but he found it. Guess what, the next day he locked the computer to the radiator with a steel lock so that I couldn't hide it again." Similarly, the two other parents also mentioned their discomfort with Internet addiction.

Another issue raised about the negative sides of the Internet is that one of the spouses would meet and make friends with someone of the opposite sex. This opinion was voiced by the three parents in this group. Parents feared that their children could be exposed to pornographic content, their grades could get lower, and they could meet the wrong people and be exposed to deception.

The B group's concerns about the Internet: These parents complain that the Internet prevents people from doing their daily chores and makes them lazy. Another concern is that it 'put a mask' on people identities by making them anonymous. The parents expressed their concerns in the following terms: "The Internet allows people to remain anonymous; no face, no identity ... bad things can happen"; "Internet-related developments can be dangerous if not monitored"; "It is addictive and a waste of time"; "It cannot be controlled" and "There are satanic groups out there and they may join virtual communities".

\section{Positive View of the Internet}

Three parents in the A group mention the positive aspects of the Internet: communication with distant relatives, watching movies, doing research for homework, quick access to information. In addition, one parent said that when they couldn't provide their children with 
adequate information, the children solved problems easily by investigating on the Internet. The positive aspects of the Internet were proposed as follows: "It helps homework"; "It provides instant access to information"; "Children do not have to look for books and this is really convenient for them"; "I can communicate with my friends at a distance"; "It reduces my boredom", and "We follow the news and various agendas on the Net".

The B group's positive view of the Internet: The parents in this group used expressions such as "It provides us with immediate information"; "It involves us in social life and eliminates our loneliness"; "It allows us to make friends with others and share our thoughts"; "It makes life easier for shopping and banking transactions"; "You can access what you're looking for very quickly"; "It increases options and interpersonal interaction".

\section{Fear of the Internet and its Source}

The aim of the question about the sources of the fear of the Internet is to see whether the media plays a role in this or not. The sources of these fears are mainly events in the family and immediate surroundings and other means of communication.

First of all, one of the A group parents stated that her personal experiences and what she has heard from her immediate surroundings caused her fears and she had previously been harassed through her mobile phone, which deeply affected her. In addition, the fact that one family in their circle lost a great amount of money because their child gambled on the Internet increased her fears. Another parent mentioned among the causes of her fear that their neighbors were divorced because of the Internet and the mother ran away with someone else, leaving her home and her children.

One of the parents in this group expressed their distrust of the Internet as follows: saying "The credit card number of someone close to me was stolen and he lost money, so we are scared to do online shopping". Another one stated that she was affected by TV programs she watched such as MügeAnlı (a TV reality show in Turkey), which made her anxious and pessimistic, and to see the Internet as evil. She added that even her children had warned her saying "Mother, that's enough, doesn't watch these programs any longer". A further parent said that she was affected by the fact that on television married couples met other people by means of the Internet and ran away together. Thus, it can be argued that different means of 
communication, especially television, intensified the fear of the Internet, especially regarding the deception and exploitation of children by strangers.

The B group's fear of the Internet: This group generally states that the Internet may be hazardous if used without appropriate controls. They agree that the use of the Internet is not related to age but to the social environment of the individuals and that the Internet environment is dangerous because it provides people living in restricted and limited communities with the opportunity to expand their environment and unconsciously communicate with people they do not know. Comments included: "The Internet is not dangerous but the people who use it are"; "When children go and play outside, you can warn them not to leave the front door, but when they are online inside the house, you can't know where they might get to by means of the Internet". Moreover, they emphasize that the influence of the media, especially theatrical dramatization of events on television increase their anxiety. The opinion of this group is that they are influenced by news of such things as harassment and blackmail, learned not only from the television but also from the Internet.

\section{Media Awareness:}

The first words which the A group immediately associated with the media are news reports causing panic terror, news about violence against women, women beaten publicly (trending news stories), also news from unidentified sources and exaggeration of events. The fact that the media have good and bad aspects was noted as well. They assess the media mostly through a consideration of television. Knowledge and direct experience of media is minimal in this group, but they make neither efforts nor requests to be better informed. Economic conditions and lack of time may have been influential in this situation. The source of fears about the Internet appears to be largely television. The B group associated the media with the increased communication and keeping informed about the world. They see the old media as passive and the new media as active.

\section{The Control of the Internet, Setting Time Limits, Rules:}

In general, the A group does not want their children to use the Internet during school time and they try to set time limits. They state that they are able to exercise control over their children and that they know their Facebook log in or e-mail passwords; however families 
were unable to distinguish between log in passwords and clearly their control was inadequate due to their ignorance of the subject.

Those who set the rules are generally the mothers. However, the mothers admit that they are unable to the boys obey the rules laid down. One parent attended a course to learn about the computer and then set a password on the computer at home, but the child just hacked the passwords. The parents refer to their children's competence on the Internet, saying, "My child knows more than us", and "Sometimes he exceeds his father's knowledge". They advise their children, as follows: "Be careful and don't let them deceive you"; "Be careful about strangers"; "Don't find a girlfriend on the Net, look around"; "I tell my children what I have heard on television and ask them not to see strangers". One parent remarked that setting extreme limits or rules is unsuccessful: "I don't ban the Internet. When I introduced a ban at first, that limitation made my children more aggressive and more problems arose". Another parent emphasized that boys do not obey the rules as much as girls and parents with daughters expressed the same opinion.

The B group also generally set time limits. They develop certain methods of monitoring their children's activities on the Internet for example, opening a Facebook account of their own, surfing the Internet with the children for a limited period of time, searching for information together, exemplifying by narrating negative events about someone else's experience (mirror tactic), repeating continuously that private information such as name, address, or telephone number shouldn't be given to anyone or any website that promotes violence. Some parents mention that they try to raise their children's awareness by giving examples instead of giving advice.

\section{The Future of the Media:}

The B group states that although the changing media does pose dangers, it will remain part of their lives and they will continue to use it because they need it. However, certain parents of the A group say they regret purchasing an Internet connection and wish they had never started using it. 
During the interviews, all of the parents except two describe their children as children who obey rules, do what they are told by their fathers and mothers and are under control; in other words, the children are depicted in the way their parents want to see them.

\section{Discussion and Conclusion}

The media guides individuals in the contemporary world where access to knowledge has gained great importance. Media literacy and media awareness have a key role that individuals will need throughout their lives and serve as a filter that checks information. It is essential that individuals should be introduced to media literacy from the time of childhood so that they are protected against negative impacts. Parents have an important role in children's first experiences with the media. Also, parents set examples for children according to their own knowledge and experiences and guide children according to their own perspectives. For this reason, parents' awareness of the media is of great importance. On the other hand, it is not likely that parents can protect their children when they cannot even control themselves. The A group parents suffer from lack of education and try to avoid unfamiliar technology. On the other hand, the B group parents do not feel any discomfort with the advancement of technology and try to keep up with it. This situation creates a difference between the two groups.

Today, the rapid development and changes occurring especially in the field of science and technology "require that the old value judgments and understanding of life change" and raises issues between generations about "reaching the same level of adaptation to the shared environment". While the former generations and low-income families have difficulty in keeping up with innovations, they firmly hold to the old understanding of life and cannot empathize with the young since they tend to see their children as their extension or copy. Nevertheless, the young are open to new ideas and they are more successful in adapting to rapid changes. They strive to revolt and to be independent as a part of this growth period and avoid all the values of the older generation. The different ways of socialization for the two different generations, the adolescents' attempt to impose themselves as adults because of gaining new opportunities, and parents' difficulty in adapting to the new status of adolescents lead to the emergence of a generation conflict between adolescents and adults. 
The changing and developing technology creates its own values and relationships. These values are more easily adopted by the younger generation, who do not have a fully-grown personality yet but have high level of energy in terms of psychological and physiological aspects. On the other hand, the older generation is hesitant to change their values due to their low level of energy and exhibit a conservative attitude fearing that they could lose what they obtained by struggling for years. This attitude is much more pronounced in lower-income groups, who usually have a low level of education.

Reliability is an issue, which the new media fails. Stolen passwords, stolen money from bank accounts, financial losses due to ignorance and misuse cast doubt on the reliability of this media. In addition, the fact that the Council of Europe declared the social media as the new platform of cybercrime is a sign that this distrust will grow parents' fear of the Internet even more. However, with all these pros and cons, the changing media exists in life practices and it will do so in the future. 


\section{References}

Bissette, D. C. (2006) “Internet Pornography Statistics: 2003”, http://healthymind.com/s-portstats.html

Canbek G. \&Sağıroğlu Ş., (2007) ÇocuklarınVeGençlerinBilgisayarVe Internet Güvenliği, PoliteknikDergisi, Cilt 10, Say1 1, s. 33-39.

Düzgün, Ş. (2006) Eğitimsürecinde Ana-BabalarınÇocuklarına Olan Etkileri, SosyalBilimlerEnstitüsüDergisi, Cilt 8, sayı 2.

e-dergi.atauni.edu.tr/index.php/SBED/article/view/362

http://www.tuik.gov.tr.

Internet: "ÇocukPornosuna Son! 2 SaniyedeKişininYaşınıBelirleyenYazılım”, MilliyetGazetesi, http://teknoloji.milliyet.com.tr/detay.asp?id=1406 (Şubat 2006).

Kaya,M. (2003) BeyinGöçü/ Erozyonu, ÜniversiteveToplum, Cilt. 3, s. 6.

Livingstone, S. (2001) “Online Freedom \& Safety for Children”, Institute for Public Policy Research, IPPR/Citizens Online Research Publication No.3.

Livingstone, S., Bober, M., (2005) “UK Children Go Online”, Economic and Social Research Council. 